\title{
Olanzapin depot kan gi en tilstand forenlig med sentralt antikolinergt syndrom
}

\author{
Sentralt antikolinergt syndrom kan være livstruende. Tilstanden skyldes utilsiktet sterk antikolinerg virkning \\ av en rekke medikamenter. I sjeldne tilfeller kan injeksjon av olanzapinpamoat gi en tilstand med delir og \\ sedasjon som er forenlig med syndromet. Ved sentralt antikolinergt syndrom er fysostigmin et effektivt \\ antidot. Fysostigmin er rapportert å gi god respons ved peroral overdose av olanzapin. Man bør vurdere \\ behandling med fysostigmin dersom delir og sedasjon oppstår etter injeksjon av olanzapin.
}

Det finnes rikelig med acetylkolin og tilhørende reseptorer i sentalnervesystemet. Acetylkolin aktiverer to ulike typer kolinerge reseptorer: muskarinfølsomme (muskarinerge) og nikotinfølsomme (nikotinerge). Sentralt antikolinergt syndrom skyldes blokade av muskarinerge-kolinerge reseptorer i sentalnervesystemet. Symptomatologien er kompleks og tilstanden kan lett overses, spesielt postoperativt. Diagnosen er basert på kliniske symptomer og tegn, utelukking av andre tilstander og ved at symptomene lindres ved bruk av fysostigmin $(1,2)$. Syndromet var vanligere da skopolamin og atropin ble benyttet som premedikasjon før generell anestesi. Tidligere er tilstanden blitt kalt «postoperativt delirium», «atropinforgiftning» og «antikolinergt syndrom» (2). Sentralt antikolinergt syndrom er beskrevet i psykiatrisk, akuttmedisinsk og anestesiologisk litteratur. Men det er som nevnt en tilstand som er lett å overse, og det er derfor også blitt kalt «den glemte diagnose» (2).

\section{Virkninger av fysostigmin}

Fysostigmin hemmer nedbrytning av acetylkolin og øker dermed nivået av acetylkolin i kolinerge synapser. Medikamentet passerer blod-hjerne-barrieren og vil raskt gi sentralnervøse effekter. Stoffet vil derfor reversere både sentrale og perifere effekter av atropin, skopolamin og mange andre medikamenter med en antikolinerg virkningskomponent (3). Økende doser fysostigmin kan gi tydelig økt spyttsekresjon, bradykardi, kramper, tap av kontroll over urinblære og tarm og over respirasjonsmuskulatur, med kvelningsdød som følge (2). Atropin vil som regel greie å snu forgiftningsbildet, men andre tiltak som stimulerer sirkulasjon og respirasjon kan være nødvendige (2).

\section{Fysostigmin som antidot}

Virkningen av fysostigmin ved atropinforgiftning har vært kjent i omtrent 150 år $(1,4)$. I 1976 presenterte Rupreht \& Dworacek en detaljert gjennomgang av behandlingen av mer enn 200 tilfeller med sentralt antikolinergt syndrom der fysostigmin ble brukt (5). Kunnskapen om fysostigmin som antidot ved sentralt antikolinergt syndrom har til tross for dette vært påfallende lite utbredt $(1,4)$. Også i siste utgave av store lærebøker i farmakologi er det svært kort omtalt (3). I en undersøkelse av antidotberedskap på sykehus i Norge fant Solheim og medarbeidere at om lag $80 \%$ av sykehusene hadde fysostigmin, og forfatterne foreslo at alle sykehus skulle ha det som en del av akuttberedskapen (6).

\section{Medikamenter med antikolinerge effekter}

Mange store medikamentgrupper har en antikolinerg virkningskomponent som lett glemmes fordi medikamentene er markedsført under andre hovedmerkelapper. Eksempler er psykofarmaka, antihistaminer, antikolinerge antiparkinsonmidler, visse antiarytmika, visse opioider og visse kvalmestillende midler $(1,7)$. Ved samtidig bruk av flere medikamenter fra disse grup-

\section{«Man bør vurdere behandling med fyso- stigmin dersom delir og sedasjon oppstår etter injeksjon av olanzapin»}

pene kan derfor den totale antikolinerge påvirkningen bli betydelig. Hos eldre kan dette føre til problemer i hverdagen (8). Særlig stor blir antikolinerg påvirkning ved inntak av overdoser ved uhell eller i suicidal hensikt. Bruk av fysostigmin kan da nokså umiddelbart reversere de fleste symptomene, og rask effekt av fysostigmin bidrar dermed til at diagnosen sentralt antikolinergt syndrom kan stilles (1).

Sammenliknet med andre atypiske antipsykotika har olanzapin og klozapin spesielt høy affinitet for muskarinerge-kolinerge reseptorer $(7,9,10)$. Det er rapportert at peroralt inntak av olanzapin i store mengder har gitt en tilstand forenlig med sentralt antikolinergt syndrom (11). Bruk av fysostigmin reverserte symptomene nesten komplett og dokumenterte dermed at blokade av muskarinerge-kolinerge reseptorer var involvert.
Selv om det i denne rapporten bare er referert to kasuistikker, er den åpenbart å regne som holdbart konsept for at høydose olanzapin gir sentralnervøs antikolinerg påvirkning som er fysostigminfølsom.

Peroralt inntak av overdoser olanzapin i suicidal hensikt er rapportert tidligere $(12,13)$. I begge rapportene nevnes «antikolinerge symptomer», men ingen av dem nevner muligheten for å undersøke om tilstanden er fysostigminfølsom $(12,13)$.

\section{Postinjeksjonssyndrom ved olanzapin}

Olanzapin er tilgjengelig som depotpreparat for intramuskulær injeksjon. For en del pasienter er det definitivt en fordel å få tilført medikament i denne formen, f.eks. for å øke etterlevelse av behandlingen. Hver episode med tilbakefall regnes som uheldig og belastende med tanke på å oppnå full remisjon $(14,15)$. Ved $<0,1 \%$ av injeksjonene og hos ca. $2 \%$ av pasientene som får tilført olanzapin på denne måten (16), er det beskrevet et postinjeksjonssyndrom som i enkelte tilfeller starter nokså umiddelbart etter at injeksjonen er avsluttet $(17,18)$. Dette fenomenet er kalt postinjeksjonsdelirium-/sedasjonssyndrom (postinjection delirium/sedation syndrome, PDSS). Symptomatologien er forenlig med olanzapinoverdose (f.eks. sedasjon, konfusjon, uklar tale, forandret ganglag, bevisstløshet). En studie konkluderer med at på tross av korrekt injeksjonsteknikk kan en sjelden gang injisert olanzapin lekke inn i en blodåre, kanskje på grunn av en skade i åreveggen ved injeksjonen, og forårsake en veldig høy serumkonsentrasjon av olanzapin og gi det nevnte syndromet (19).

Postinjeksjonssyndromet opptrer etter injeksjon av olanzapin, men ikke etter injeksjon av risperidon eller paliperidon (20). Det er overensstemmende med at risperidon og paliperidon har svært lav affinitet for muskarinerge-kolinerge reseptorer sammenliknet med olanzapin (7). I to omfattende oversiktsartikler nevnes ikke muligheten for at postinjeksjonssyndromet i det minste delvis kan være forenlig med et sentralt antikolinergt syndrom $(15,20)$. Ingen av disse arbeidene refererer til studien der man hadde brukt og demon- 
strert effekt av fysostigmin hos to pasienter (11), men konkluderer med at det ikke finnes noe spesifikt antidot mot olanzapin. Det er riktig at det ikke finnes et spesifikt antidot mot olanzapin som substans, men det finnes et antidot mot den virkningskomponenten som er forårsaket av muskarinergkolinerg blokade: fysostigmin. Etter vår vurdering har historien gjentatt seg nok en gang. «Den glemte diagnose» må igjen hentes frem, det er ingen merkelapp på olanzapin som forteller at det har en antikolinerg virkning.

\section{Fysostigmin som beredskap}

Fysostigmin bør være på plass blant antidoter på linje med flumazenil og nalokson. Imidlertid forsterker fysostigmin effektene av endogent acetylkolin, noe man må kjenne til for sikker bruk $(1,2)$. Det bør derfor håndteres av anestesileger/medisinsk personell som har tilstrekkelig kompetanse. Depotformen av olanzapin bør administreres av trent personell som kjenner til muligheten for et postinjeksjonssyndrom med sentrale antikolinerge effekter.

Vi mener at pasientene må observeres i minst tre timer etter injeksjon av olanzapin. Ved administrasjon på institusjoner uten anestesiologisk personell i umiddelbar nærhet må de som administrerer olanzapin intramuskulært eventuelt tilkalle hjelp hvis postinjeksjonssyndromet skulle vise seg. Fysostigmin kan da administreres av ambulansetjenesten, eventuelt i samråd med lokal AMK-sentral. Fysostigmin inngår p.t. ikke i ambulansetjenestens medikamentarsenal (Anders Holtan, personlig meddelelse, 2012). Vi anbefaler at fysostigmin skal finnes på de stedene som utfører intramuskulær injeksjon av olanzapin.

Tor Skomedal

tor.skomedal@medisin.uio.no

Sigrid Hanem

Terje Dybvik

Stein Opjordsmoen Itner
Tor Skomedal (f. 1947) er dr.med., spesialist i klinisk farmakologi og professor ved Farmakologisk institutt, Universitetet i Oslo.

Forfatter har fylt ut ICMJE-skjemaet og oppgir ingen interessekonflikter.

Sigrid Hanem (f. 1953) er dr.med., spesialist i anestesiologi og overlege ved Avdeling for anestesiologi, Akuttklinikken, Oslo universitetssykehus, Rikshospitalet.

Forfatter har fylt ut ICMJE-skjemaet og oppgir ingen interessekonflikter.

Terje Dybvik (f. 1954) er spesialist i anestesiologi og overlege ved Avdeling for anestesiologi, Akuttklinikken, Oslo universitetssykehus, Ullevål. Forfatter har fylt ut ICMJE-skjemaet og oppgir ingen interessekonflikter.

Stein Opjordsmoen Ilner (f. 1942) er dr.med., spesialist i nevrologi og i psykiatri, har mange års erfaring som overlege i psykiatri ved Oslo universitetssykehus og er professor emeritus ved Institutt for klinisk medisin, Universitetet i Oslo.

Forfatter har fylt ut ICMJE-skjemaet og oppgir ingen interessekonflikter.

\section{Litteratur}

1. Breivik $H$. Det sentrale antikolinerge syndrom og dets behandling med fysostigmin. Tidsskr Nor Lægeforen 1975; 95: 1771-76.

2. Moos DD. Central anticholinergic syndrome: a case report. J Perianesth Nurs 2007; 22: 309-21.

3. Taylor P. Anticholinesterase agents. I: Brunton L, Chabner B, Knollman B, red. Goodman \& Gilman's The Pharmacological Basis of Therapeutics. 12. utg Berkshire: McGraw-Hill Medical, 2011: 239-54.

4. Duvoisin RC, Katz R. Reversal of central anticholinergic syndrome in man by physostigmine. JAMA 1968; 206: 1963-5

5. Rupreht J, Dworacek B. Central anticholinergic syndrome in anesthetic practice. Acta Anaesthesiol Belg 1976; 27: 45-60.

6. Solheim L, Andrew E, Jacobsen D. Antidotberedskap i Norge. Tidsskr Nor Lægeforen 2002; 122: 1111-3

7. Chew ML, Mulsant BH, Pollock BG et al. Anticholinergic activity of 107 medications commonly used by older adults. J Am Geriatr Soc 2008; 56 : $1333-41$.
8. Rovner BW David A, Lucas-Blaustein MJ et al. Self-care capacity and anticholinergic drug levels in nursing home patients. Am J Psychiatry 1988; 145: 107-9.

9. Meyer JM. Pharmacotherapy of psychosis and mania. I: Brunton L, Chabner B, Knollman B, red. Goodman \& Gilman's The Pharmacological Basis of Therapeutics. 12. utg. Berkshire: McGraw-Hill Medical, 2011: 417-55.

10. Chew ML, Mulsant BH, Pollock BG et al. A model of anticholinergic activity of atypical antipsychotic medications. Schizophr Res 2006; 88: 63-72.

11. Weitzberg M, Mazzola JL, Bird SB et al. Altered mental status from olanzapine overdose treated with physostigmine. Clin Toxicol 2006; 44: 319-25.

12. Cohen LG, Fatalo A, Thompson BT et al. Olanzapine overdose with serum concentrations. Ann Emerg Med 1999; 34: 275-8.

13. O'Malley GF, Seifert S, Heard K et al. Olanzapine overdose mimicking opioid intoxication. Ann Emerg Med 1999; 34: 279-81

14. Robinson D, Woerner MG, Alvir JM et al. Predictors of relapse following response from a first episode of schizophrenia or schizoaffective disorder. Arch Gen Psychiatry 1999; 56: 241-7.

15. Lindenmayer JP. Long-acting injectable antipsychotics: focus on olanzapine pamoate. Neuropsychiatr Dis Treat 2010. 6.261-7.

16. Summary of Product Characteristics (SPC). www.legemiddelverket.no/Legemiddelsoek/Sider/ Preparatomtale.aspx?pakningld=00c58560-901d4788-a2cb-c68bf347cb55\&searchquery $=\& f=\#$ SPCHUMAN 0408 (18.2.2013).

17. Detke HC, McDonnell DP, Brunner E et al. Postinjection delirium/sedation syndrome in patients with schizophrenia treated with olanzapine longacting injection, I: analysis of cases. BMC Psychiatry 2010; 10: 43

18. Kane JM, Detke HC, Naber D et al. Olanzapine long-acting injection: a 24-week, randomized, double-blind trial of maintenance treatment in patients with schizophrenia. Am J Psychiatry 2010 167: $181-9$

19. McDonnell DP, Detke HC, Bergstrom RF et al. Post-injection delirium/sedation syndrome in patients with schizophrenia treated with olanzapine long-acting injection, II: investigations of mechanism. BMC Psychiatry 2010; 10: 45.

20. Novakovic V, Adel T, Peselow E et al. Long-acting injectable antipsychotics and the development of postinjection delirium/sedation syndrome (PDSS). Clin Neuropharmacol 2013; 36: 59-62.

Mottatt 15.3. 2013, første revisjon innsendt 7.6. 2013, godkjent 8.10. 2013. Redaktør Kristin Viste.

Publisert først på nett.

a. Engelsk oversettelse på www.tidsskriftet.no 